Economics Development Analysis Journal 6(4)(2017)

\title{
Analisis Pengaruh Faktor Sosial Ekonomi terhadap Tingginya Mortalitas Penduduk
}

\author{
Riyani Suryaningsih ${ }^{\bowtie}$
}

Jurusan Ekonomi Pembangunan, Fakultas Ekonomi, Universitas Negeri Semarang

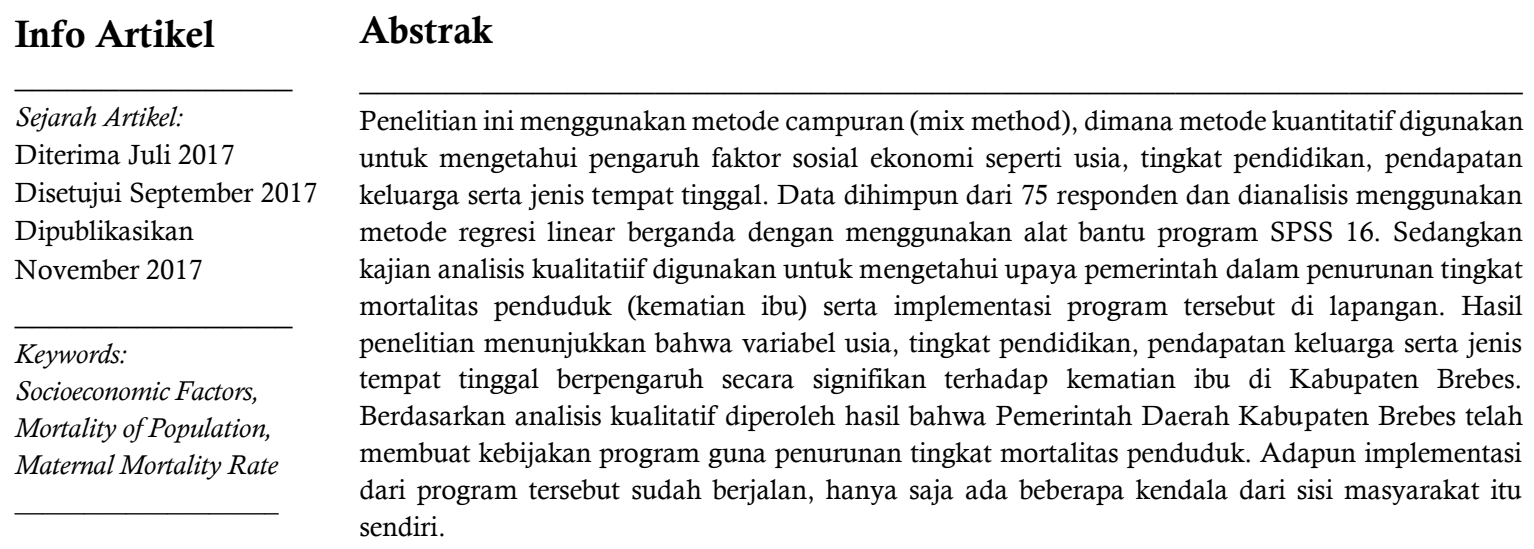

\section{Abstract}

This research uses mix method, where quantitative method is used to know the influence of socio-economic factors such as age, education level, family income and type of residence. The data were collected from 75 respondents and analyzed using linear regression method using SPSS 16 program tool. While the qualitative analysis study was used to know the government effort in decreasing the mortality rate of the population (maternal mortality) and the implementation of the program in the field. The results showed that the variables of age, education level, family income and type of residence have significant effect influence to maternal mortality in Brebes Regency. Based on the qualitative analysis, it is found that the local government of Brebes Regency has made program policy to decrease the mortality rate of the population. The implementation of the program has been running, it's just that there are some obstacles from the side of society itself.

Gedung L2 Lantai 2 FE Unnes

Kampus Sekaran, Gunungpati, Semarang, 50229

E-mail: edaj@mail.unnes.ac.id 


\section{PENDAHULUAN}

Penduduk merupakan faktor yang strategis dalam pembangunan. Pertumbuhan penduduk merupakan faktor yang sangat mempengaruhi usaha pembangunan yang sedang dilaksanakan oleh pemerintah. Pertumbuhan penduduk yang besar di negara - negara berkembang dapat menambah kerumitan masalah - masalah dalam pembangunan. Menurut Soetjipto Wirosardjono (1988) masalah kependudukan di Indonesia sangat erat hubungannya dengan perkembangan penduduk yang meningkat pesat, penyebaran penduduk yang tidak merata, kurangnya sistem pendidikan serta layanan kesehatan dan penduduk usia muda yang kurang produktif. Pertumbuhan populasi mempengaruhi banyak fenomena seperti usia struktur populasi suatu negara, migrasi internasional, ketidaksetaraan ekonomi, dan ukuran angkatan kerja suatu negara (Peterson, 2017). Dalam konteks empiris, pertumbuhan penduduk dapat dipertimbangkan untuk memiliki dampak positif terhadap pertumbuhan ekonomi. Secara khusus, perubahan populasi bisa berdampak kuat pada ekonomi pertumbuhan (Rosado, 2017).

Dinamika atau pertumbuhan penduduk di suatu negara pada hakekatnya didasarkan oleh tiga elemen utama yaitu fertilitas, mortalitas, dan migrasi (Mantra, 2000). Mortalitas atau kematian merupakan salah satu dari tiga faktor demografis selain fertilitas dan migrasi, yang dapat mempengaruhi jumlah penduduk dan struktur atau komposisi umur penduduk. Mortalitas atau kematian penduduk pada suatu daerah erat kaitannya dengan kualitas penduduk di daerah tersebut dalam hal derajat kesehatan masyarakat yang akan turut mempengaruhi kualitas penduduk atau masyarakat sebagai subjek pembangunan.

Tingkat mortalitas penduduk dalam masa tertentu dapat mempengaruhi proses pembangunan ekonomi di masa yang akan datang. Sedikitnya kuantitas serta rendahnya kualitas sumberdaya manusia yang dimiliki suatu bangsa dapat menjadi penghambat bagi bangsa itu sendiri dalam melaksanakan pembangunan ekonomi. Selain itu, hubungan antara pembangunan ekonomi dengan tingkat mortalitas penduduk sifatnya saling mempengaruhi (Arshia et'al, 2013). Menurut Sulaiman (2015) peran human capital dan teknologi dalam menentukan pertumbuhan telah mengalami perdebatan untuk waktu yang lama, dari dasar teoritis sampai pengujian empiris.

Tingkat mortalitas penduduk atau dalam hal ini tingkat kematian ibu memiliki pengaruh terhadap pembangunan atau pertumbuhan ekonomi. Kematian atau mortalitas memiliki efek negatif dan signifikan secara statistik pada pertumbuhan ekonomi, peningkatan satu standar deviasi pada kematian memberikan pengaruh penurunan pertumbuhan ekonomi tahunan antara 0,8 dan 1,1 persen. Tingkat kematian orang dewasa yang tinggi menginduksikan pelaku ekonomi untuk berinvestasi lebih sedikit yang akan berdampak pada penurunan pertumbuhan ekonomi atau minimal tingkat kematian orang dewasa yang tinggi telah menghambat pengembangan pertumbuhan ekonomi negara dan yang paling buruk hubungan yang negatif antara kematian atau mortalitas dan pertumbuhan dapat menyebabkan kemiskinan diri (Peter Lorentzen, John McMillan dan Romain Wacziarg, 2008). Yoses et'al dalam Sede Igbaudumhe Peter dan Izilien Elizabeth I (2014) juga menyatakan bahwa angka kematian ibu memiliki pengaruh yang negatif dan signifikan terhadap Produk Domestik Bruto (PDB), yaitu kematian ibu mengurangi PDB per kapita sebesar US $\$ 0,36$ per tahun.

Salah satu hal penting yang mempengaruhi Human Development Indeks (HDI) adalah kualitas hidup perempuan. Apabila kualitas hidup perempuan rendah maka indeks pembangunan manusia juga rendah dan keberhasilan pembangunan daerah (Amin Pujiati, 2012). Kematian ibu merupakan masalah besar bagi negara berkembang. Ini berarti kemampuan untuk memberikan pelayanan kesehatan masih memerlukan perbaikan kesehatan yang bersifat menyeluruh dan lebih bermutu.

\section{Menurut World Health Organization} (WHO), pada tahun 2013 Angka Kematian Ibu (AKI) di dunia sebanyak 210 per 100.000 kelahiran hidup, AKI di negara berkembang sebanyak 230 per 100.000 kelahiran hidup dan AKI di negara maju 16 per 100.000 kelahiran hidup. Angka Kematian Ibu di Asia Timur sebanyak 33 per 
100.000 kelahiran hidup, Asia Selatan sebanyak 190 per 100.000 kelahiran hidup, Asia Tenggara sebanyak 140 per 100.000 kelahiran hidup dan Asia Barat sebanyak 74 per 100.000 kelahiran hidup (World Health Organization, 2014).

Sebagaimana negara berkembang lainnya, Indonesia pada saat ini sedang mengalami masalah pertumbuhan penduduk diikuti dengan tingginya angka kematian maternal. Tingginya angka kematian maternal di Indonesia sesungguhnya mencerminkan rendahnya kualitas hidup dan kondisi sosial ekonomi masyarakat di Indonesia. Angka Kematian Ibu (AKI) sebagai salah satu indikator kesehatan ibu dewasa ini jumlahnya masih tinggi di Indonesia jika dibandingkan dengan jumlah AKI di negara lainnya.

Tabel 1. Jumlah Angka Kematian Ibu (AKI) di Indonesia dan Negara Lain Tahun 2013

\begin{tabular}{ll}
\hline \multicolumn{1}{c}{ Negara } & $\begin{array}{c}\text { Jumlah AKI } \\
\text { per 100.000 } \\
\text { KH }\end{array}$ \\
\hline Indonesia & 190 \\
Malaysia & 29 \\
Filipina & 120 \\
Singapura & 6 \\
Vietnam & 49 \\
Thailand & 26 \\
Brunei Darussalam & 27
\end{tabular}

Sumber : World Health Organization (WHO), 2014.

Hingga saat ini sudah ada program program kebijakan publik di bidang kesehatan yang dirancang oleh pemerintah guna meningkatkan derajat kesehatan masyarakatnya pada umumnya dan guna menurunkan angka kematian ibu (AKI) pada khususnya. Salah satu program tersebut adalah program MDG's (Millenium Development Goal's), dimana program ini merupakan program yang disepakati secara global oleh 189 negara perserikatan bangsa - bangsa (PBB) yang dimulai pada bulan september tahun 2000 dan akan berakhir pada tahun 2015. Dalam salah satu tujuan ataupun target dari program Millenium Development
Goal's tersebut pada poin 5a yaitu untuk meningkatkan kesehatan ibu dengan target tujuan menurunkan angka kematian ibu (AKI) sampai 102 per 100.000 kelahiran hidup.

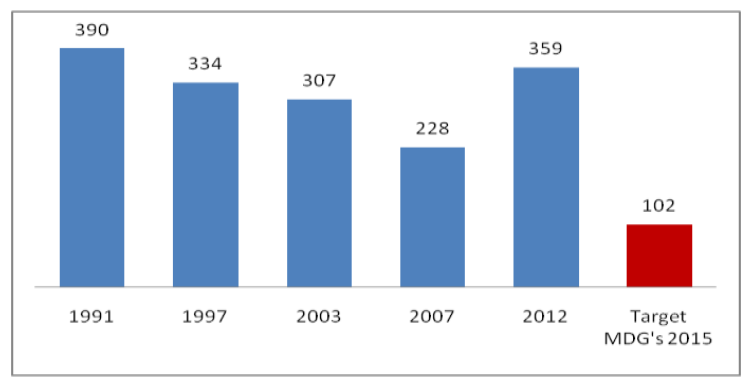

Gambar 1. Grafik Perkembangan Angka Kematian Ibu (AKI) dan Target Angka Kematian Ibu (AKI) dalam MDG's 2015 di Indonesia.

Sumber: Badan Kependudukan dan Keluarga Berencana Nasional (BKKBN) dalam Prakarsa, 2013.

Di Provinsi Jawa Tengah sendiri, Angka Kematian Ibu (AKI) masih sangat tinggi dan jauh dari target ataupun tujuan dari Millenium Development Goal's (MDG's).

Tabel 2. Jumlah Angka Kematian Ibu di Provinsi Jawa Tengah

\begin{tabular}{cc}
\hline Tahun & $\begin{array}{c}\text { Jumlah Angka } \\
\text { Kematian Ibu } \\
\text { (AKI) }\end{array}$ \\
\hline 2011 & 668 \\
2012 & 675 \\
2013 & 668 \\
2014 & 711 \\
2015 & 619 \\
2016 (s.d bulan & 251 \\
Mei) & \\
\hline
\end{tabular}

Sumber : Badan Pusat Statistik, data diolah.

Sedangkan di Kabupaten Brebes, Angka Kematian Ibu (AKI) jumlahnya tertinggi dibandingkan dengan kabupaten atau kota di Jawa Tengah bahkan Kabupaten Brebes merupakan penyumbang terbesar angka kematian ibu (AKI) di Jawa Tengah, yaitu sebanyak 73 kasus di tahun 2014. 
Tabel 3. Jumlah Angka Kematian Ibu (AKI) Menurut Kabupaten/Kota di Jawa Tengah Tahun 2014

\begin{tabular}{lc}
\hline Kabupaten/Kota & $\begin{array}{c}\text { Jumlah Angka } \\
\text { Kematian Ibu } \\
\text { (AKI) }\end{array}$ \\
Kab. Cilacap & 36 \\
Kab. Banyumas & 33 \\
Kab. Purbalingga & 14 \\
Kab. Banjarnegara & 20 \\
Kab. Kebumen & 12 \\
Kab. Purworejo & 5 \\
\hline
\end{tabular}

Kab. Wonosobo 11

Kab. Magelang

Kab. Boyolali

Kab. Klaten

Kab. Sukoharjo

Kab. Wonogiri

Kab. Karanganyar

Kab. Sragen

Kab. Grobogan

Kab. Blora

Kab. Rembang

Kab. Pati

Kab. Kudus

Kab. Jepara

Kab. Demak

Kab. Semarang

Kab. Temanggung

Kab. Kendal

Kab. Batang

Kab. Pekalongan

Kab. Pemalang

Kab. Tegal

Kab. Brebes

Kota Magelang

Kota Surakarta

Kota Salatiga

Kota Semarang

Kota Pekalongan

Kota Tegal

Sumber : Profil Kesehatan Kabupaten/Kota
Tahun 2014.

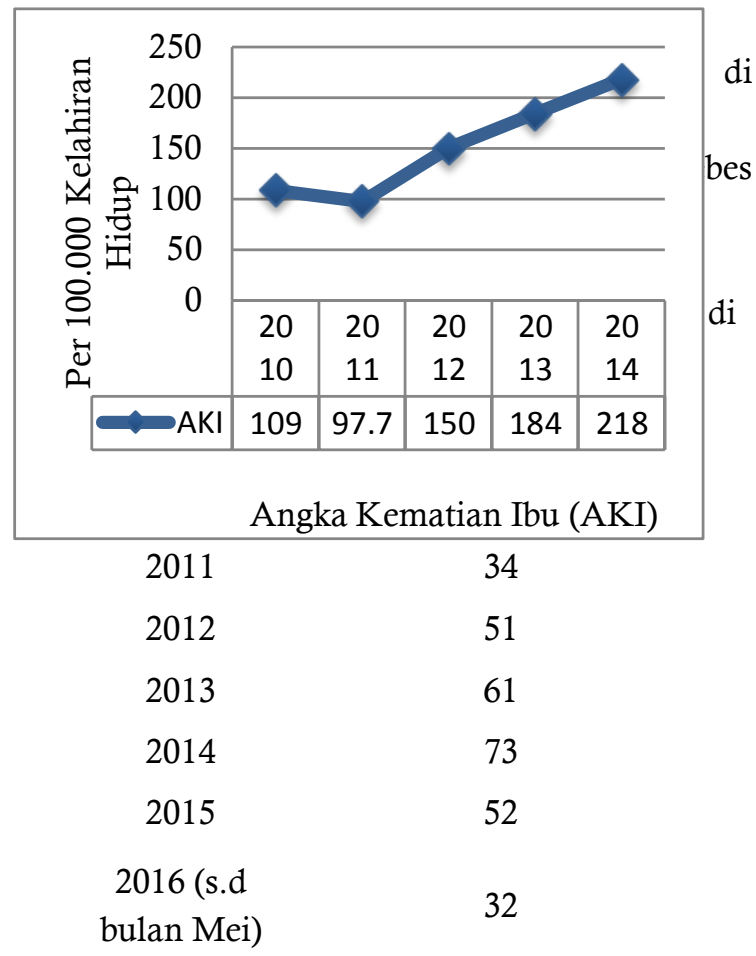

Sumber: Profil Kesehatan Kabupaten Brebes.

Tingginya angka kematian ibu atau kematian maternal disebabkan oleh beberapa faktor, baik faktor medis maupun faktor non medis seperti faktor ekonomi, sosial dan budaya. Faktor sosial ekonomi seperti pengetahuan tentang kesehatan, gizi dan kesehatan lingkungan serta kemiskinan merupakan faktor individu dan keluarga yang mempengaruhi mortalitas dalam masyarakat. Faktor sosial ekonomi merupakan penyebab dasar (distal) mortalitas atau kematian, mengingat keadaan sosial ekonomi sebagian masyarakat yang masih berada digaris kemiskinan, fasilitas kesehatan dan tenaga kesehatan yang belum tersebar secara merata tenaga kesehatan di seluruh wilayah Indonesia (SDKI 2012).

Tingginya angka kematian maternal yang terjadi di suatu negara mencerminkan rendahnya kualitas hidup masyarakat dan kondisi sosial ekonomi mereka. Hal ini sesuai dengan Schultz (1997) yang berpendapat bahwa terjadinya penurunan angka kematian ibu dan bayi erat kaitannya dengan perbaikan kondisi sosial ekonomi bagi seluruh lapisan masyarakat. Selain itu, pendapat Schultz diperkuat oleh pendapat Dutta \& 
Kapur (1982) yang menyatakan bahwa tinggi rendahnya angka kematian ibu dan bayi pada saat proses kelahiran pada suatu negara merupakan indikator yang penting tentang kondisi sosialekonomi dan kesehatan dari negara yang bersangkutan. Sedangkan Burcheet (2009) berpendapat bahwa kemiskinan dapat menjadi sebab rendahnya peran serta masyarakat pada upaya kesehatan.Faktor lainnya yang juga mempengaruhi tinggi rendahnya angka kematian ibu yaitu ketersediaan jumlah fasilitas kesehatan di suatu wilayah atau daerah. Dimana, semakin banyaknya jumlah fasilitas kesehatan yang tersedia maka semakin terpenuhilah kebutuhan masyarakat akan layanan kesehatan serta kemudahan keterjangkaun guna meningkatkan derajat kesehatan masyarakat tersebut yang juga turut berdampak pada indeks pembangunan manusia daerah tersebut melalui angka harapan hidup. Kabupaten Brebes merupakan daerah peringkat 8 dengan jumlah fasilitas kesehatan terbanyak seJawa Tengah yaitu sejumlah 1.937 unit.

Tabel 5. Jumlah Penduduk, Jumlah Fasilitas Kesesehatan, Jumlah Angka Kematian Ibu dan IPM Kabupaten/Kota di Jawa Tengah.

\begin{tabular}{|c|c|c|c|c|c|c|c|c|}
\hline \multirow[t]{2}{*}{ Kabupaten/Kota } & \multicolumn{2}{|c|}{$\begin{array}{c}\text { Jml } \\
\text { Penduduk(Orang) }\end{array}$} & \multicolumn{2}{|c|}{$\begin{array}{l}\text { Jml FasKes } \\
\text { (Unit) }\end{array}$} & \multicolumn{2}{|c|}{ AKI(Orang) } & \multicolumn{2}{|c|}{ IPM(\%) } \\
\hline & Jumlah & Rank & Jumlah & Rank & Angka & Rank & Angka & Rank \\
\hline Kab. Cilacap & 1685573 & 2 & 2495 & 4 & 36 & 6 & 67.77 & 22 \\
\hline Kab. Banyumas & 1620918 & 4 & 2981 & 1 & 33 & 7 & 69.89 & 16 \\
\hline Kab. Purbalingga & 889214 & 19 & 1435 & 24 & 14 & 19 & 67.03 & 27 \\
\hline $\begin{array}{l}\text { Kab. } \\
\text { Banjarnegara }\end{array}$ & 895986 & 18 & 1830 & 13 & 20 & 11 & 64.73 & 33 \\
\hline Kab. Kebumen & 1181006 & 10 & 2461 & 6 & 12 & 26 & 66.87 & 28 \\
\hline Kab. Purworejo & 708038 & 29 & 1912 & 10 & 5 & 33 & 70.37 & 14 \\
\hline Kab. Wonosobo & 773280 & 26 & 1504 & 22 & 11 & 28 & 65.7 & 30 \\
\hline Kab. Magelang & 1233695 & 8 & 2673 & 2 & 14 & 19 & 67.13 & 25 \\
\hline Kab. Boyolali & 957857 & 15 & 2076 & 7 & 14 & 19 & 71.74 & 12 \\
\hline Kab. Klaten & 1154040 & 12 & 2580 & 3 & 20 & 11 & 73.81 & 7 \\
\hline Kab. Sukoharjo & 856937 & 22 & 1410 & 26 & 13 & 24 & 74.53 & 5 \\
\hline Kab. Wonogiri & 945817 & 16 & 2466 & 5 & 10 & 29 & 67.76 & 23 \\
\hline $\begin{array}{l}\text { Kab. } \\
\text { Karanganyar }\end{array}$ & 848255 & 24 & 1626 & 18 & 17 & 16 & 74.26 & 6 \\
\hline Kab. Sragen & 875600 & 20 & 1898 & 11 & 13 & 24 & 71.1 & 13 \\
\hline Kab. Grobogan & 1343960 & 6 & 1918 & 9 & 43 & 3 & 68.05 & 21 \\
\hline Kab. Blora & 848369 & 23 & 1568 & 21 & 12 & 26 & 66.22 & 29 \\
\hline Kab. Rembang & 614087 & 30 & 1409 & 27 & 14 & 19 & 68.18 & 20 \\
\hline Kab. Pati & 1225594 & 9 & 1897 & 12 & 17 & 16 & 68.51 & 19 \\
\hline Kab. Kudus & 821136 & 25 & 970 & 30 & 26 & 9 & 72.72 & 9 \\
\hline Kab. Jepara & 1170797 & 11 & 1348 & 28 & 19 & 14 & 70.02 & 15 \\
\hline Kab. Demak & 1106328 & 13 & 1489 & 23 & 17 & 16 & 69.75 & 17 \\
\hline Kab. Semarang & 987557 & 14 & 1774 & 15 & 20 & 11 & 71.89 & 11 \\
\hline $\begin{array}{l}\text { Kab. } \\
\text { Temanggung }\end{array}$ & 738915 & 27 & 1754 & 16 & 14 & 19 & 67.07 & 26 \\
\hline Kab. Kendal & 934643 & 17 & 1598 & 20 & 19 & 14 & 69.57 & 18 \\
\hline Kab. Batang & 736397 & 28 & 1432 & 25 & 23 & 10 & 65.46 & 31 \\
\hline Kab. Pekalongan & 867573 & 21 & 1601 & 19 & 39 & 5 & 67.4 & 24 \\
\hline
\end{tabular}


Riyani Suryaningsih / Economics Development Analysis Journal 6 (4) (2017)

\begin{tabular}{lllllllll}
\hline Kab. Pemalang & 1284236 & 7 & 1326 & 29 & 40 & 4 & 63.7 & 34 \\
Kab. Tegal & 1420132 & 5 & 1782 & 14 & 47 & 2 & 65.04 & 32 \\
Kab. Brebes & 1773379 & 1 & 1937 & 8 & 73 & 1 & 63.18 & 35 \\
Kota Magelang & 120373 & 35 & 213 & 34 & 2 & 34 & 76.39 & 4 \\
Kota Surakarta & 510077 & 31 & 704 & 31 & 7 & 30 & 80.14 & 3 \\
Kota Salatiga & 181193 & 34 & 310 & 33 & 2 & 34 & 80.96 & 1 \\
Kota Semarang & 1672999 & 3 & 1737 & 17 & 33 & 7 & 80.23 & 2 \\
Kota Pekalongan & 293704 & 32 & 471 & 32 & 6 & 31 & 72.69 & 10 \\
Kota Tegal & 244998 & 33 & 195 & 35 & 6 & 31 & 72.96 & 8 \\
Jawa Tengah & 33522663 & & 56780 & & & & 69.49 & \\
\hline
\end{tabular}

Sumber:BPS,datadiolah.

Selain target atau tujuan penurunan angka kematian ibu (AKI) seperti yang telah tercantum dalam program Millenium Development Goal's (MDG's) tersebut, di Indonesia sendiri juga terdapat beberapa program guna menangani permasalahan tersebut diantaranya program Keluarga Berencana, program Making Pregnancy Safer (MPS), program Expanding Maternal and Neonatal Survival (EMAS) diluncurkan sejak akhir tahun 2011, program Jaminan Persalinan (Jamersal).

Tak jauh berbeda dengan program yang ada di Pemerintah Pusat, di Jawa Tengah sendiri juga telah menerapkan program - program tersebut, namun untuk program Expanding Maternal and Neonatal Survival (EMAS) hanya ada tujuh daerah Kabupaten / Kota di Jawa Tengah yang mendapat pendampingan program ini, salah satunya yaitu Kabupaten Brebes. Namun, meskipun sudah banyak program yang telah dilaksanakan, akan tetapi angka kematian ibu di Jawa Tengah masih juga tinggi. Oleh sebab itu, target penurunan Angka Kematian Ibu (AKI) ini akan dilanjutkan dalam program lanjutan yaitu Sustainable Development Goal's (SDG's) serta target penurunan Angka Kematian Ibu (AKI) ini juga masuk dalam program prioritas Jawa Tengah yang tertuang dalam Rencana Pembangunan Jangka Menengah Daerah (RPJMD).

Masalah kesehatan keluarga dalam hal ini angka kematian ibu atau kematian maternal merupakan salah satu problem yang sangat perlu mendapat perhatian, sangat pentingnya peran ibu dalam keberlangsungan keluarga. Selain pentingnya peran perempuan dalam keluarga baik dalam bidang sosial maupun ekonomi, peran perempuan dalam daerah pun sangat penting, hal ini dikarenakan terdapat hubungan searah antara peran wanita dalam pembangunan dengan fundamental ekonomi daerah (pertumbuhan ekonomi dan pendapatan perkapita daerah, indikator pembangunan manusia atau Human Development Index/HDI) artinya peran wanita dalam pembangunan yang meningkat, menyebabkan fundamental ekonomi daerah meningkat dan apabila kualitas hidup perempuan rendah maka indeks pembangunan manusia juga rendah serta keberhasilan pembangunan rendah (Amin Pujiati, 2012). Oleh sebab itu, penelitian mengenai mortalitas dalam hal ini angka kematian ibu itu sangat penting.

Berangkat dari fenomena ataupun permasalahan ini serta mengingat penyebab mendasar kematian ibu adalah faktor sosial ekonomi dan demografi, terutama kemiskinan, tingkat pendidikan yang rendah dan ketidaktahuan tentang perkembangan seksual dan proses reproduksi, budaya, kondisi bias gender dalam masyarakat dan keluarga, dan lokasi tempat tinggal yang terpencil. Serta dengan memperhatikan bahwa sudah banyak program yang telah dilaksanakan oleh pemerintah guna menangani permasalahan tersebut dan sebagai informasi bahwasannya Kabupaten Brebes merupakan satu dari tujuh daerah di Jawa Tengah yang mendapat pendampingan program EMAS serta jumlah fasilitas kesehatan yang tersedia di Kabupaten Brebes jumlahnya tergolong banyak (jumlah fasilitas kesehatan terbanyak di wilayah Eks Karesidenan Pekalongan dan nomor 8 se-Jawa Tengah), namun meskipun begitu jumlah kematian ibu di Kabupaten Brebes sendiri 
cenderung mengalami kenaikan dari tahun ke tahun. Oleh sebab itu peneliti tertarik untuk melakukan penelitian guna mengetahui analisis pengaruh faktor sosial ekonomi terhadap tingginya mortalitas penduduk di Kabupaten Brebes serta bagaimana upaya atau peran pemerintah dalam menangani permasalahan tersebut dan apakah upaya atau program yang telah dibuat oleh pemerintah dapat berjalan atau diimplementasikan dengan baik di masyarakat serta untuk mengetahui ketidakefektifan implementasi program tersebut apakah berasal dari kinerja pemerintah ataukah berasal dari masyarakat terkait dengan daya tangkap, pengetahuan serta pemahaman masyarakat terkait program tersebut.

\section{METODE PENELITIAN}

Jenis penelitian yang digunakan pada penelitian ini adalah penelitian observasional dengan pendekatan metode campuran (mixed methods), dimana metode kuantitatif digunakan untuk mengetahui pengaruh faktor sosial ekonomi seperti usia, tingkat pendidikan, pendapatan keluarga serta jenis tempat tinggal dan dianalisis menggunakan metode regresi linear berganda dengan menggunakan alat bantu program SPSS 16. Sedangkan kajian analisis kualitatiif dengan teknik indepth interview (wawancara mendalam) digunakan untuk mengetahui upaya pemerintah dalam penurunan angka kematian ibu serta implementasi program tersebut dilapangan.

Adapun model regresi dapat dituliskan dengan persamaan dibawah ini :

$$
\begin{gathered}
\mathrm{Y}=\mathrm{a}+b_{1} X_{1}+b_{2} X_{2}+b_{3} X_{3}+b_{4} X_{4}+\mathrm{e} . . \\
\text { atau } \\
\mathrm{Y}=\mathrm{a}+b_{1} D_{1}+b_{2} X_{2}+b_{3} X_{3}+b_{4} D_{4}+\mathrm{e} .
\end{gathered}
$$

\section{Dimana :}

$\mathrm{Y}=$ kematian ibu

$\mathrm{a}=$ konstanta

$b_{0}-b_{5}=$ koefisien persamaan regresi

$X_{1}=$ Usia responden (ibu yang mengalami kematian), bernilai 1 jika usia beresiko ( $<20$ tahun dan $>35$ tahun) serta bernilai 0 jika usia tidak beresiko (21-35 tahun).

$X_{2}=$ Tingkat Pendidikan
$X_{3}=$ Pendapatan keluarga

$X_{4}=$ Jenis tempat tinggal (Dummy), 1 jika bertempat tinggal di perkotaan dan 0 jika bertempat tinggal di pedesaan.

$\mathrm{e}=$ error term

Sedangkan teknik pengambilan sampel yang digunakan dalam penelitian adalah teknik non probability sampel dengan metode sampling yang digunakan adalah purposive sampling (bertujuan). Sampel atau responden yang diambil dalam penelitian ini sebanyak 75 orang yang berasal dari 3 kecamatan, dengan pertimbangannya bahwa 3 kecamatan ini merupakan kecamatan dengan jumlah angka kematian ibu terbanyak di Kabupaten Brebes dari tahun 2012 - 2015 serta ke3 kecamatan ini merupakan kecamatan yang wilayah atau daerahnya terletak dengan pusat pemerintahan sehingga untuk aksesibilitas atau keterjangkauan terhadap fasilitas, kondisi infrastruktur, serta pelayanan yang baik jika dibandingkan dengan wilayah lain yang berada lebih jauh dari pusat kota. Akan tetapi dengan keberadaan wilayahnya yang strategis, jumlah angka kematian ibu di 3 kecamatan ini justru yang paling banyak di Kabupaten Brebes.

\section{HASIL DAN PEMBAHASAN}

Berdasarkan analisis data penelitian, diperoleh hasil penelitian sebagai berikut :

Tabel 6. Koefisien Determinasi $\left(\mathrm{R}^{2}\right)$

Model Summary

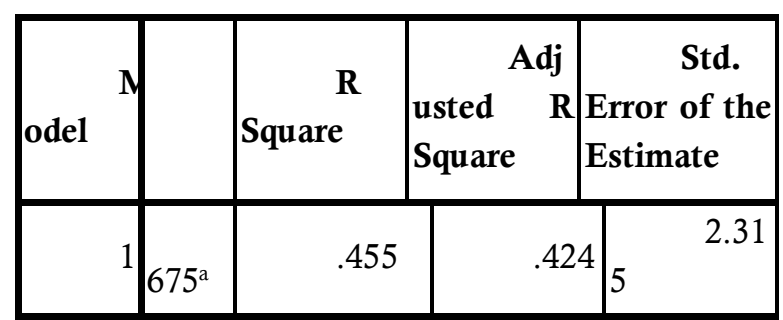

Sumber : Data Penelitian, diolah.

a. Predictors: (Constant), TT, PDDK, USIA, YK

b.Dependent Variable: KI

Berdasarkan hasil SPPS, diperoleh nilai koefisien determinasi $\left(R^{2}\right)$ sebesar 0,675 . Sesuai dengan kriteria pengujian $R^{2}=0,675$ terletak 
anatara 0 sampai 1 , dengan demikian maka dapat disimpulkan bahwa variabel usia, tingkat pendidikan, jenis pekerjaan, pendapatan keluarga serta jenis tempat tinggal dapat menjelaskan variabel kematian ibu sebesar 67,5 persen, sedangkan sisanya sebesar 32,5 persen dijelaskan oleh variabel lain diluar model.

Tabel 7. Uji Signifikansi Simultan (Uji F)

ANOVA $^{\mathrm{b}}$

\begin{tabular}{llllll}
\hline Model & $\begin{array}{c}\text { Sum of } \\
\text { Squares }\end{array}$ & Df & $\begin{array}{c}\text { Mean } \\
\text { Square }\end{array}$ & F & Sig. \\
\hline $\begin{array}{l}\text { 1 Regre } \\
\text { ssion }\end{array}$ & 313.529 & 4 & 78.382 & 14.626 & $.000^{\mathrm{a}}$ \\
& & & & & \\
$\begin{array}{l}\text { Resid } \\
\text { ual }\end{array}$ & 375.138 & 70 & 5.359 & & \\
Total & 688.667 & 74 & & & \\
\hline
\end{tabular}

Sumber : Data Penelitian, diolah

a. Predictors: (Constant), TT, PDDK, USIA, YK

b. Dependent Variable: KI

Berdasarkan dari hasil SPSS, nilai signifikansi Uji $\mathrm{F}$ ialah 0,000 dengan nilai alpha 0,05 . Hal ini berarti nilai signifikansi atau probabilitas lebih kecil dari alpha sehingga Ho ditolak dan Ha diterima. Artinya, secara bersamasama antara usia, tingkat pendidikan, jenis pekerjaan, pendapatan keluarga dan jenis tempat tinggal berpengaruh signifikan terhadap kematian ibu.

Tabel 8. uji Signifikansi Parsial (Uji t)

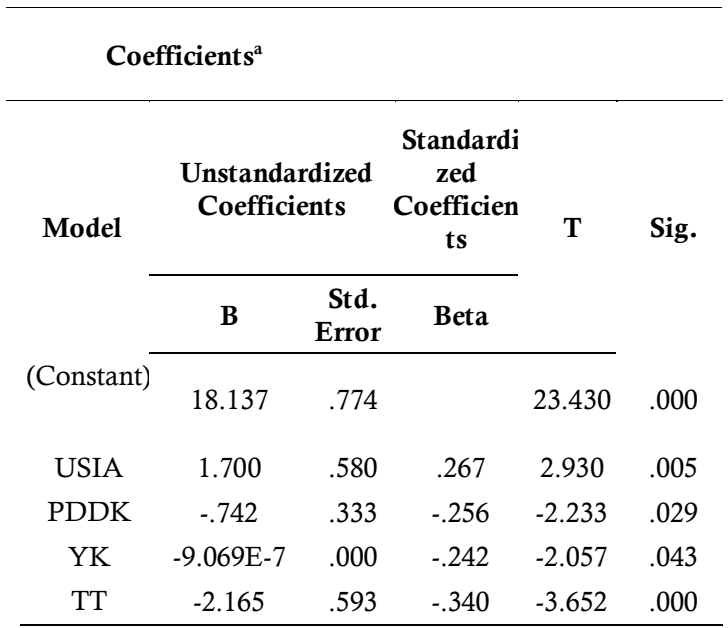

Sumber : Data Penelitian, diolah.

a. Dependent Variable: KI
Persamaan regresi berganda berdasarkan Tabel 8 dapat dituliskan sebagai berikut :

$\mathrm{Y}=18,137+1,700 U S I A-0,742 P D D K-9,069 \mathrm{E}-$

$7 Y K-2.165 T T+\mathrm{e}$

Usia adalah lama waktu hidup atau ada sejak dilahirkan. Variabel usia dalam penelitian ini berbentuk dummy, bernilai 1 jika usia beresiko $(<20$ tahun dan $>35$ tahun) serta bernilai 0 jika usia tidak beresiko (20-35 tahun). Variabel usia dalam penelitian ini memiliki pengaruh yang signifikan terhadap kematian ibu. Artinya, tinggi rendahnya usia atau beresiko dan tidaknya usia yang dimiliki oleh responden memberi pengaruh yang signifikan terhadap terjadi atau tidaknya kematian ibu.

Berdasarkan hasil olah data dalam penelitian ini, variabel usia memiliki pengaruh yang signifikan dengan nilai koefisien sebesar 1,700 artinya jumlah kematian ibu pada usia beresiko lebih besar 1,700 dibandingan pada usia tidak beresiko. Nilai koefisien regresi yang bernilai positif menunjukkan bahwa peningkatan usia beresiko responden akan menaikkan jumlah kematian ibu dengan asumsi bahwa variabel lain dianggap konstan atau tetap.

Peningkatan jumlah kematian ibu sejalan dengan peningkatan usia responden (ibu hamil) dikarenakan semakin tinggi usia seseorang dalam melahirkan semakin meningkat pula resikonya. Menurut Sarwono (2008) kematian maternal pada wanita hamil dan melahirkan pada usia dibawah 20 tahun ternyata 2 sampai 5 kali lebih tinggi daripada kematian maternal yang terjadi pada usia 20 sampai 29 tahun, dan kematian maternal akan meningkat kembali sesudah usia 30 sampai 35 tahun.

Usia seorang wanita pada saat hamil sebaiknya tidak terlalu muda dan tidak terlalu tua. Umur yang kurang dari 20 tahun atau lebih dari 35 tahun, berisiko tinggi untuk melahirkan.

Hasil penelitian ini sejalan dengan penelitian Marisa Prohapsari dengan judul "Analisis faktor sosial ekonomi terhadap angka kematian maternal di Jawa Timur" yang menyatakan bahwa usia responden berpengaruh secara signifikan terhadap kematian ibu, serta 
penelitian dari Justina Fatbian dkk (2013) juga menyatakan bahwa usia berpengaruh signifikan terhadap kematian maternal.

Menurut Green dalam Notoatmodjo (2007:17) mengatakan bahwa yang paling mempengaruhi kesehatan seseorang adalah perilaku dan faktor non perilaku. Perilaku sendiri terbentuk karena adanya proses pendidikan sebelumnya yang melalui beberapa tahap hingga kemudian terbentuk pola perilakunya. Pendidikan, latar pendidikan formal serta informal akan sangat berpengaruh pada seluruh aspek kehidupan para ibu mulai dari segi pikiran, perasaan maupun tindakannya.

Variabel pendidikan dalam penelitian ini memiliki pengaruh yang signifikan terhadap kematian ibu. Artinya tinggi rendahnya tingkat pendidikan yang dimiliki oleh ibu berpengaruh terhadap terjadi atau tidaknya kematian ibu.

Berdasarkan hasil analisis regresi, variabel pendidikan dalam penelitian ini memiliki pengaruh yang signifikan terhadap kematian ibu dengan nilai koefisien sebesar - 0,742 . Artinya, jika variabel pendidikan naik sebesar satu satuan (tahun) maka kematian ibu angka berkurang sebesar 0,742 satu satuan (orang).

Hasil penelitian ini sejalan dengan penelitian dari Arulita Ika Fibrina, dan Masrida Sinaga yang menyatakan bahwa rendahnya tingkat pendidikan berpengaruh terhadap kematian ibu. Serta penelitian dari Ni Nyoman Mestri Agustini dkk (2013) yang menyatakan bahwa responden atau ibu dengan tingkat pengetahuan (pendidikan) yang tinggi memiliki kemungkinan cakupan pelayanan antenatal lengkap 9,250 kali lebih tinggi daripada ibu yang tingkat pengetahuan (pendidikan) nya rendah.

Angka Kematian Ibu yang begitu tinggi salah satunya karena tingkat pendidikan para ibu di Indonesia yang masih sangat rendah. Wanita yang berpendidikan tinggi cenderung lebih memperhatikan kesehatan diri dan keluarganya, sedangkan wanita dengan tingkat pendidikan yang rendah, menyebabkan kurangnya pengertian mereka akan bahaya yang dapat menimpa ibu hamil maupun bayinya terutama dalam hal kegawatdaruratan kehamilan dan persalinan.
Pendapatan keluarga adalah pendapatan atau penghasilan yang diterima oleh rumah tangga yang bersangkutan baik yang berasal dari pendapatan kepala keluarga maupun pendapatan anggota rumah tangga. Besarnya koefisien regresi untuk variabel pendapatan keluarga dalam penelitian ini berpengaruh secara signifikan dan mempunyai nilai negatif sebesar 9,069E-7. Artinya apabila pendapatan keluarga bertambah atau naik sebesar satu satuan rupiah maka jumlah kematian ibu akan berkurang atau turun sebesar 9,069E-7 satu satuan (orang). Koefisien regresi yang bernilai negatif menunjukkan bahwa peningkatan pendapatan keluarga akan berdampak pada penurunan jumlah kematian ibu dengan asumsi bahwa variabel yang lainnya dianggap konstan atau tetap.

Hasil dalam penelitian ini sejalan dengan penelitian dari Arulita Ika Fibriana, Masrida Sinaga, serta penelitian dari Nurul Maisyara dkk (2013) yang menyatakan bahwa tingginya jumlah atau angka kematian ibu dipengaruhi oleh rendahnya tingkat pendapatan keluarga (kemiskinan).

Apabila ada kenaikan pendapatan keluarga, daya beli atau kesadaran masyarakat terhadap kesehatan (permintaan jumlah barang atau jasa kesehatan) akan meningkat. Ada hubungan (asosiasi) antara tingginya pendapatan dengan besarnya permintaan akan pemeliharaan kesehatan, terutama dalam hal pelayanan kesehatan modern. Jika pendapatan meningkat maka garis pendapatan akan bergeser kekanan sehingga jumlah barang dan jasa kesehatan yang diminta meningkat.

Daya beli atau kemampuan masyarakat untuk memenuhi kebutuhannya di bidang kesehatan berbeda antar masyarakat yang satu dengan masyarakat yang lainnya. Pada masyarakat yang berpendapatan lebih tinggi, daya beli atau kemampuan memenuhi kebutuhannya dalam bidang kesehatan lebih tinggi daripada masyarakat yang berpendapatan lebih rendah. Hal ini dikarenakan, pada masyarakat berpendapatan rendah, akan mencukupi kebutuhan barang terlebih dahulu, setelah kebutuhan akan barang tercukupi baru kemudian akan mengkonsumsi barang atau jasa kesehatan. 
Tempat tinggal dalam penelitian ini memiliki pengaruh yang signifikan terhadap kematian ibu. Artinya, jenis tempat tinggal turut memberikan pengaruh atau andil yang signifikan dalam terjadi atau tidaknya kematian ibu.

Adapun tempat tinggal tersebut terkait dengan aspek geografi misalnya tempat tinggal berada di wilayah pedesaan atau perkotaan. Masyarakat dengan tingkat kemampuan ekonomi yang rendah umumnya banyak terdapat di daerah pedesaan dengan kondisi kesehatan yang rendah jika dibandingkan dengan masyarakat yang hidup didaerah perkotaan. Hal ini disebabkan karena di daerah pedesaan jumlah fasilitas kesehatan yang masih terbatas serta aspek aksesibilitas pelayanan kesehatan. Hasil Riskesdas juga menunjukkan bahwa cakupan program kesehatan ibu dan reproduksi umumnya rendah pada ibu-ibu di pedesaan dengan tingkat pendidikan dan ekonomi rendah (Kementerian Kesehatan, 2011).

Variabel tempat tinggal dalam penelitian ini bersifat dummy, yaitu bernilai 1 jika bertempat tinggal di perkotaan dan bernilai 0 jika bertempat tinggal di pedesaan. Berdasarkan hasil analisis regresi, variabel tempat tinggal dalam penelitian ini memiliki pengaruh yang signifikan dengan nilai koefisien bernilai negatif sebesar 2,165. Artinya, kematian ibu pada tempat tinggal yang berada di perkotaan lebih kecil 2,165 daripada tempat tinggal yang berada di daerah pedesaan.

Hasil penelian ini sejalan dengan penelitian dari Masrida Sinaga dengan judul "Beberapa faktor sosial demografi yang berhubungan dengan tingginya angka kematian ibu di Provinsi Nusa Tenggara Timur" serta penelitian dari Justina Fatbian dkk (2013) yang menyatakan bahwa tempat tinggal memiliki pengaruh yang signifikan terhadap kematian ibu atau kematian maternal.

Sedangkan untuk hasil analisis atau kajian kualitatif diperoleh hasil bahwa Pemerintah Kabupaten Brebes telah melaksanakan program guna penurunan angka kematian ibu, dengan pelaksanaan riil dilapangannya seperti pelaksanaan $A N C$ Terpadu, penyuluhan ataupun sosialisai pada saat kelas ibu hamil serta posyandu, pengadaan desa siaga, peningkatan ketrampilan petugas kesehatan melalui pelatihan, pertemuan, orientasi ketrampilan serta penguatan jejaring rujukan dengan Rumah Sakit swasta maupun pemerintah dan koordinasi.

Implementasi program tersebut dilapangan sudah berjalan, dan seiring berjalannya waktu akan terus dilakukan perbaikan sarana dan prasarana guna peningkatan pelayanan di masyarakat serta tetap dilakukan koordinasi, pengawasan dan pembinaan terhadap Puskesmas. Hanya saja masih ada kendala yang berasal dari sisi masyarakat seperti rendahnya tingkat kesadaran masyarakat akibat rendahnya tingkat pendidikan, rendahnya keikutsertaan masyarakat dalam program KB yang mengakibatkan jumlah penduduk masih tinggi dan banyak ibu hamil dengan usia yang beresiko, serta rendahnya daya beli masyarakat akibat rendahnya kondisi ekonomi atau pendapatan masyarakat.

\section{SIMPULAN}

Simpulan dari hasil penelitian ini adalah variabel usia, tingkat pendidikan, tingkat pendapatan keluarga dan jenis tempat tinggal memiliki pengaruh yang signifikan tehadap kematian ibu.

Berdasarkan analisis kualitatif diperoleh hasil bahwa pemerintah daerah Kabupaten Brebes telah membuat kebijakan program guna penurunan angka kematian ibu. Adapun implementasi dari program tersebut sudah berjalan, hanya saja ada beberapa kendala dari sisi masyarakat itu sendiri

Adapun saran yang dapat diberikan dalam penelitian ini yaitu perlunya peningkatan kesejahteraan masyarakat atau usaha penurunan kemiskinan, serta sosialisasi atau pendekatan yang lebih intensif kepada masyarakat.

\section{DAFTAR PUSTAKA}

Agustini, Ni Nyoman Mesti dkk. 2013. Hubungan antara Tingkat Pengetahuan Ibu dan Dukungan Keluarga dengan cakupan Pelayanan Antenatal di Wilayah Kerja Puskesmas Buleleng I. Jurnal Magister Kedokteran Keluarga Vol I No 12013 hal 67-79.

Badan Kependudukan dan Keluarga Berencana Nasional dalam https://www.bkkbn.go.id/ 
Badan Perencanaan Pembangunan Nasional. 2012. Survei Demografi dan Kesehatan Indonesia. Jakarta : Bappenas RI.

Badan Pusat Statistis dalam https://www.bps.go.id/

Badan Pusat Statistis Kabupaten Brebes dalamhttps://www.brebeskab.bps.go.id/, 2015. Kabupaten Brebes dalam Angka. 2015a. Statistik Daerah Kabupaten Brebes

Dinas Kesehatan Kabupaten Brebes. 2014. Profil Kesehatan Kabupaten Brebes Tahun 2014. Brebes : Dinkes Brebes. 2014a. Profil Kesehatan Kabupaten/Kota Tahun 2014. Brebes : Dinkes Brebes.

Fatbinan, Justina dkk. 2013. Faktor Resiko Kematian Maternal di RSUD Piere Paolo Magreti Saumlaki Kabupaten Maluku Nusa Tenggara Barat. Universitas Hasanudin Makasar.

Fibriana, Arulita Eka Fibriana. 2007. Faktor - faktor Resiko yang Mempengaruhi Kematian Maternal (Studi Kasus di Kabupaten Cilacap). Tesis. Undip Semarang.

Maisyara, Nurul dkk. 2013. Analisis Jarak Tempat Persalinan dI Kelurahan Batua Kota Tahun 2013. Universitas Hasanuddin Makasar.

Mantra, Ida Bagus. 2009. Demografi Umum. Yogyakarta : Pustaka Pelajar Offset.

Prakarsa. 2013. Angka Kematian Ibu (AKI) Melonjak, Indonesia Mundur 15 Tahun. Prakarsa Policy Review. Jakrta : Prakarsa.

Probohapsari, Marisa. 2007. Analisis Faktor Sosial Ekonomi Terhadap Angka Kematian Maternal di Jawa Timut tahun 2001 - 2004. Skripsi. Universitas Airlangga. Skripsi.

Peterson, E.W. F. 2017. The Role of Population in Economic Growth. SAGE Journal, 7(4).

Pujiati, Amin. 2012. Kausalitas Antara Fundamental Ekonomi Daerah dan Peran Wanita dalam Pembangunan. Jurnal Ekonomi Pembangnunan Volume 13, Nomor 1, Juni 2012, hlm.46-61.

Rosado, A. J., Sanchez, M. I. A. 2017. From Population Age Structure and Savings Rate to Economic Growth: Evidence from Ecuador. International Journal of Economics and Financial Issues, 7(3), 352-361.

Sulaiman, C., Bala, U., Tijani, B. A., Waziri, S. I., Maji, I. B. 2015. Human Capital, Technology, and Economic Growth: Evidence From Nigeria. SAGE Journal, 5(4).

Sinaga, Masrida. 2007. Beberapa Faktor Sosial Demografi yang Berhubungan dengan Tingginya Angka Kematian Ibu di Provinsi Nusa Tenggara Timur.
Wirosardjono, Soetjipto. 1988. Pertumbuhan Penduduk Indonesia. Prisma No 3 Tahun XVII. Jakarta :LP3ES.

World Health Organization. 2011. International Statistical Classification of Disease and Related Health Problems.

2013. Indonesia Maternatal and Perinatal Health Profile. Departement of Maternal, Newborn, Child and Adolescent Health (MCA/WHO).

2015. Indonesia :WHO Statistical Profile. WHO Global Health Observatory.2 